CESIS Electronic Working Paper Series

Paper No. 348

THE FATE OF PATENTS: AN EXPLORATORY ANALYSIS OF PATENTS AS IPO SIGNALS OF REPUTATIONAL ADVANTAGE

\author{
Nada Basir \\ Mehdi Beyhaghi \\ Ali Mohammadi
}

March, 2014 
THE FATE OF PATENTS:

\title{
AN EXPLORATORY ANALYSIS OF PATENTS AS IPO SIGNALS OF REPUTATIONAL ADVANTAGE
}

\author{
Running Head: Patents as IPO Signals of Reputational Advantage
}

\author{
Nada Basir ${ }^{1}$, Mehdi Beyhaghi ${ }^{2}$, Ali Mohammadi ${ }^{3}$
}

Acknowledgement: We are grateful for comments and insights from Preet Aulakh, Ellen Auster, Chiara Franzoni, Eileen Fischer, Anoop Madhok, Silvio Vismara and the seminar participants at the Schulich School of Business, York University. We would also like to thank Rosemarie Zeidonis for her insightful suggestions and encouragement. We received useful suggestions from participants at the Academy of Management 2012 Annual Meeting in Boston, the CCSE Workshop, Politecnico di Milano, USPTO-Ewing Marion Kauffman Foundation Conference on Innovation and Entrepreneurship and at the DRUID Conference Barcelona, where earlier versions of this paper have been presented.

\begin{abstract}
Drawing on the reputation literature and signaling theory, this article builds on work that looks at patents as reputation signals. We build a multi-industry database of patents that expire due to lack of maintenance fee payments and test for a relationship between these patents and the firm's IPO date. We find a significant and positive relationship between the likelihood of patents expiring due to lack of maintenance fee payments and the time to IPO. We also find that patents associated with firms which are not venture capital backed, are more likely to expire. Our findings suggest that patents that are used for signaling intentions are more likely to be underutilized. Implications for research and policy are discussed.
\end{abstract}

Keywords: Patents, reputation signal, innovation, IPO, intellectual property

JEL Codes: O34, O30

\footnotetext{
${ }^{1}$ Schulich School of Business, York University, 4700 Keele Street, Toronto ON, M3J 1P3, Canada, Phone: 613219-6232, e-mail: nbasir08@schulich.yorku.ca.

2 College of Business, University of Texas at San Antonio, One UTSA Circle, San Antonio, TX 78249-0631, e-mail: mehdi.beyhaghi@utsa.edu

${ }^{3}$ Centre of Excellence in Science and Innovation Studies (CESIS), Division of Entrepreneurship and Innovation, Department of Industrial Economics and Management, Royal Institute of Technology (KTH), SE-100 44, Stockholm, Sweden, Phone: +46-08-790-6962, e-mail: almo@kth.se
} 


\section{INTRODUCTION}

The primary focus of value for many corporations has been found in their intellectual property rights with inventors spending millions of dollars to protect their inventions. In the United States alone, inventors file over 540,000 patent applications a year with the U.S. Patent and Trademark Office (USPTO), a number that has grown steadily (USPTO Annual Report, 2012). Indeed, prior research has explored the proliferation of patents arguing different motives for patenting including blocking competitors (Cohen, Nelson, and Walsh, 2000), creating "fences" around commercialized products in order to prevent others from designing and selling substitute products (Cohen et al., 2000; Shapiro, 2001), defending against patent infringement (Hall, Jaffe, and Trajtenberg, 2005; Hall and Ziedonis, 2001; Lemley, 2000, 2001), and as a way to increase a firm's reputation by showing it is innovative and an attractive investment (Blind, Edler, Frietsch and Schmoch, 2006; Hall and Ziedonis, 2001).

Once issued, a patent remains in force until 20 years after the patent application was originally filed $^{4}$. To keep this 20 -year term, the patent holder must pay maintenance fees at the four year, eight year, and twelve year mark. However, between 55 and 67 percent of issued U.S. patents lapse for failure to pay these fees before the end of their term (Lemley, 2000, 2001; Moore, 2005). In a survey of European patents, it was found that 38 percent of patents were never commercialized (Gambardella, Giuri, and Mariani, 2005). Other studies estimate that over half of all patented inventions are never commercially exploited (Lemley, 2000, 2001; Moore, 2005; Serrano, 2010; Sichelman, 2010). Although many of these undeveloped inventions can be considered commercially worthless (e.g., the anti-eating face-mask, beer bottle mini-umbrella, and weed-cutting golf club), the problem of underutilized patents arguably applies to a large share

\footnotetext{
${ }^{4}$ Although patent laws across the world bear many similarities, there are some important differences especially when it comes to first to file versus first to invent, and maintenance fee amounts and schedules. For the purpose of this paper, the focus is on the U.S. patent system as the firms in the dataset are U.S based firms.
} 
of potentially valuable inventions. The researcher Adam Jaffe has stated in testimony before Congress "the patent system - intended to foster and protect innovation - is generating waste and uncertainty that hinder and threaten the innovative process", These patents are not only underutilized, but they may also prevent other firms from using them, thus potentially thwarting the evolution of innovation within an industry. This is especially alarming in industries, such as pharmaceuticals and biotechnology, where products are highly complex and innovations are incremental, cumulative, and dependent on downstream technology.

Although previous work provides insights on why firms patent, research has been limited in offering an explanation for the dramatic number of underutilized patents and the lack of commercialization. Our study builds on work that looks at patents as reputation signals (Hsu and Zeidonis, 2008; Long, 2002); however it analyzes the fate of those patents once they have been granted, an overlooked concept in the patenting literature. The focus of this paper is on the use of patents as signals of innovativeness. By acting as a signal, patents can inform observers about attributes of not just the patent, but the patentee itself and if patents are correlated with less readily observable firm characteristics, patents can serve as a signal of firm quality, more specifically, how innovative a firm is (Lemley, 2001). We argue that patents that are used for signaling intentions are more likely to be underutilized once their purpose has been exercised.

In this article, we focus on the initial public offering (IPO), to understand patenting practices prior to a major financing event, and the consequences of these practices on the patent itself. The IPO setting constitutes an excellent setting for this study as investors face great uncertainty and a high degree of asymmetric information when valuing IPO firms. They therefore rely on various signals of potential success to help overcome these risks (Haeussler, Harhoff, and Muller, 2009), patents being one of them.

\footnotetext{
${ }^{5}$ (U.S. House of Representative Oversight Hearing on the Patent System, February 15, 2007)
} 
Using data from the National Bureau of Economic Research (NBER), we build a multiindustry database of patents that expire due to lack of maintenance fee payments and test for a relationship between these patents and the IPO date of the patent owner. We find a significant and positive relationship between the likelihood of patents expiring due to lack of maintenance fee payments and the time to IPO. More specifically, we find that as a firm gets closer to its IPO date, the higher the patenting activity, and the more likely these patents are to be expired. We also observe that patents assigned to firms which are not associated with a venture capital (VC) are more likely to expire due to lack of maintenance fee payment. We posit that firms that use patents to signal reputational advantage are more likely to avoid paying maintenance fees, thus allowing the patent to expire. We also argue that signaling is more vital for firms which are not associated with another certifying third party, such as VCs.

Overall, this study contributes to the literature in several ways. First, it complements the economic literature on drivers of patenting behavior by exploring the consequences of patents sought for reputational and signaling purposes. In doing so, this study moves beyond the question of why firms patent, to examining longitudinally the fate of these patents. This study also brings to question the use of patents as indicators of innovative activity by investors, as firms may engage in patenting practices for alternative reasons. Thus, this study has practical implications but also implications for organization researchers that use patents as an indicator of innovative capabilities.

The structure of this article is as follows. In the following section we review the literature on reputation building, and signaling theory to develop our hypotheses. In the third section we introduce our dataset, methodology and analysis. Finally we conclude with a discussion of the findings, contributions, limitations and directions for future research. 


\section{THEORY AND HYPOTHESES}

\section{Reputation Building through Signals}

The reputation of a firm is "a set of attributes ascribed to a firm, inferred from the firm's past actions" (Weigelt and Camerer, 1988, pp. 443). A firm's reputation therefore reflects stakeholder impressions of the firm's disposition to behave in a certain manner (Clark and Montgomery, 1998), and incorporates information about how a firm compares to its competitors (Rao, 1994).

The importance of a company's reputation as a source of competitive advantage is well established in the literature (e.g. Flanagan and O'Shaughnessy, 2005; Fombrun and Shanley, 1990; Hall, 1992) with reputation being argued to be one of the most important strategic resources associated with sustained competitive advantage (Amit and Schoemaker, 1993; Barnett, 1997; Barney, 1991; Flanagan and O’Shaughnessy, 2005). Although numerous studies have empirically linked firm reputation to its financial performance and social standing (Brown and Perry, 1994; Deephouse, 2000; Fombrun and Shanley, 1990; Roberts and Dowling, 2002), less research has focused on how a firm builds its reputation (Basdeo, Smith, Grimm, Rindova, and Derfus, 2006). Recent studies have emerged though which present frameworks on how reputations are constructed through market actions (Boot, Greenbaum and Thakor, 1993; Clark and Montgomery, 1998; Weigelt and Camerer, 1988), patterns of resource flows (Dierickx and Cool, 1989), market signals (Fombrun and Shanley, 1990; Heil and Robertson, 1991), and a combination of resource flows and strategic communications (Fombrun and Rindova, 1998; Reuber and Fischer, 2009; Rindova and Fombrun, 1999). These frameworks suggest that reputation formation can be broadly understood as a signaling process, in which the strategic choices of firms send signals to observers and observers use these signals to form impressions of these firms. Due to information asymmetries, stakeholders often use both actions and symbols to judge a firm's reputation and quality (Ferrier, 1997; Fombrun and Shanley, 1990; Spence, 1973). Thus, a firm's reputation is a 
“cognitive evaluation of the firm's quality that is socially constructed, but objectively held, by current and prospective constituents" (Reuben and Fischer, 2009).

Signaling theory describes the process used by decision makers in situations of information asymmetry (Spence, 1973). It posits that firms use visible signals to gain reputation and status among its stakeholders. Signaling theory has been applied in a number of settings including finance research, revealing that firms retain debt quality (Ross, 1977) or the issuance of dividends (Bhattacharya, 1979) to signal quality. In a number of IPO studies, based mostly in the accounting and finance literature, signaling theory has been used to show that managers send signals to investors to indicate firm quality and thus improve their IPO performance (e.g., Beatty, 1989 and Carter and Manaster, 1990). This line of research also demonstrates that the reputations of investment bankers (Carter, Dark, and Singh, 1998), auditors (Beatty, 1989), and venture capitalists (Megginson and Weiss, 1991) serve as signals in the IPO process. Within management, research framed in institutional theory and legitimacy has suggested that investor perceptions of board prestige signal organizational legitimacy (Certo, 2003; Higgins and Gulati, 2006). Higgins and Gulati (2006) argue that the top management team of a firm can serve as a powerful signal to investors that can in turn enable a firm to gain legitimacy, especially in young firms. Their findings show that investor decisions are affected by the employment affiliations and roles of top management team members and by partnerships the young firm has with prestigious lead underwriters.

Although the literature has investigated the signaling value of various third-party affiliations and management teams extensively, relatively little conceptual or empirical attention has been placed on the role of patents as quality signals for innovation (Hsu and Ziedonis, 2008). This study focuses on patents as signals and holds the assumption that patents meet Spence's (1974) criteria of a quality signal (Hsu and Ziedonis, 2008). According to Spence (1974), signals 
are only valuable to the extent that they are (i) observable and (ii) costly to imitate. In the context of patents, both conditions clearly apply. A patent is observable as it is documented in both the company documents, including in the prospectus documents prepared for IPO, and in the patent database of the country in which the patent is registered (for example, the USPTO in the U.S.). Finally, the purpose of a patent is to prevent others from imitating the innovation the patent describes, thus any attempts to imitate can be costly as they would be infringing on the patent. Furthermore, the direct monetary cost associated with the patenting process is estimated to be $\$ 25,000$ and can exceed this number depending on factors such as the number of countries the patent is protected in, and its complexity (Lemley, 2000).

\section{Patents as Signals in the IPO Context}

Undertaking an IPO represents a significant event in the life of a firm as it moves from being a privately held company to a public trading one. In order for a firm to go public, managers prepare a standard set of documents for potential investors. To attract investors in the IPO process, managers and the firm's investment bank provide information regarding their firm and its potential, information that typically includes the firm's patent portfolio. As the IPO firm has been privately held, potential stakeholders are unaware of how the firm will perform. Therefore, the IPO firm must convince relevant audiences, particularly investors, that the firm has long-term potential $^{6}$. To tap into a wide group of investors, firms must build a credible story that showcases their potential success. The patent portfolio of a firm helps build this story. This attempt to

\footnotetext{
${ }^{6}$ For example, a statement from the Facebook IPO states, "As of June 2012, we owned approximately 750 U.S. and foreign patents and patent applications. As of March 31, 2012, we had 774 issued patents and 546 filed patent applications in the United States and 96 corresponding patents and 194 filed patent applications in foreign countries relating to social networking, web technologies and infrastructure, and other technologies".
} 
improve their reputation in front of potential investors is referred to as prestige-enhancing strategies that help improve investor valuation of the firm.

Investors face a tremendous amount of uncertainty associated with the quality of young firms undertaking an IPO due to information asymmetries. These companies typically have short histories and no market reputation, making measurement of their growth prospects, and hence valuation, difficult. IPO firms have not had the opportunity to establish consistent performance records in public markets; therefore they suffer from a liability of market newness (Certo, 2003; Stinchcombe, 1965). To compensate, young firms offer symbols of quality to convince external parties of the firm's potential. This logic echoes the work of Pfeffer and Salancik (1978) and March and Simon (1958), who suggested that an organization's most critical activity is gaining the support of social entities and stakeholders that can ensure the firm's survival. Stakeholders are more willing to exchange resources with firms when they have a more favorable impression of them (Hall, 1992; Rindova and Fombrun, 1999).

Furthermore, the assessment of a firm's quality is a perceptual, conditional and sometimes subjective attribute (Nadeau, 2010) under conditions of risk and uncertainty. The process of patenting generates signals that help to overcome these risks of newness faced by new ventures (Haeussler, Harhoff, and Muller, 2009). Although there has been mixed findings on how effective patents are for securing returns to innovation (Cohen et al., 2000), an area where patents are viewed as highly important is in securing financing to start new ventures (Hall and Ziedonis, 2001). Studies have shown a positive relationship between patenting and the total VC invested by technology firms (Baum and Silverman, 2004; Mann and Sager, 2007), firm valuation and the likelihood to attract a prominent venture capitalist investor (Hsu and Ziedonis, 2013) and the ability to attract financing sooner (Haeussler, et al., 2009). In a study of 370 VC-backed semiconductor start-ups, Hsu and Ziedonis (2008) found that patents served as quality signals 
influencing investor estimates of start-up firm value, where a doubling in patent application stock was associated with a 28 percent boost in funding-round valuations beyond what would otherwise be expected. The authors also found that a larger patent application stock increased the likelihood of sourcing initial capital from a prominent VC. Similarly, Baum and Silverman (2004) found a positive association between USPTO patent applications and pre-IPO VC financing for biotechnology firms. Thus, we posit that as firms near critical financing events, they are likely to increase activities that signal a reputational advantage. Patents offer a signal to potential investors looking for indicators of innovation and value under conditions of uncertainty. Therefore as the IPO date draws near, firms increase their patenting activity to attract potential investors. In sum, it would be expected that:

\section{Hypothesis 1: Patenting activities increase as a firm gets closer to its IPO date.}

However, if we take the idea that patents act as reputational signals, then they may not necessarily reflect true innovative capabilities. Firms that apply for patents prior to the IPO date for signaling purposes may not have plans to commercialize or appropriate any rents from this patent (for example via licensing agreements). These patents may not necessarily even meet the requirements necessary for a patent to be granted. The purpose of these patents may be solely to

attract investors. This argument rests on the idea that these patents are used primarily for signaling purposes. This is different than the argument that their purpose to protect innovations with a latent function being their signaling capability for investors. Therefore, it would be expected that those patents that are used solely for the purpose of signaling may be of lesser quality than those patents used for rent appropriation. And thus,

Hypothesis 2: Patents filed closer to the IPO exit date are more likely to be underutilized. 
The literature investigating the signaling value of third-party affiliations demonstrates that the reputations of investment bankers (Carter, Dark, and Singh, 1998), auditors (Beatty, 1989), and venture capitalists (Megginson and Weiss, 1991) serve as signals in the IPO process. Acquiring venture capital investment is one of the most important milestones for private firms, as venture capitals not only provide financial resources, but also create value for the firm (Ueda, 2004; Gompers and Lerner, 1999; Sapiena, Manigart and Vermiel, 1996; Gorman and Sahlman, 1989). Private firms look for high quality investors (Bygrave and Timmons, 1992; Hsu, 2004; Sorenson, 2007) who can provide better value-added or lease their reputation to the firm as a signal of quality to the outside world (Hsu, 2004; Hsu and Ziedonis, 2013). Megginson and Weiss (1991) show the certifying impact of VCs in IPO markets by comparing two match samples of VC-backed and non VC-backed firms that have gone public. They show that the presence of a VC reduces the total cost of IPO and under-pricing.

Affiliation with a VC is a strong signal of quality to outside firms, therefore using patenting activity as a reputation signal is less relevant for VC-backed firms and contrarily it is more relevant for non VC-backed firms which lack alternative ways for signaling quality to outside investors. Overall, these factors suggest our third hypothesis:

Hypothesis 3: Patents filed closer to the IPO exit date are more likely to be underutilized, when issuers are not with a venture capital (that is when there is no certifying third party).

\section{METHODS}

\section{Data and Sample}

We obtain our primary sample of patents from the National Bureau of Economic Research's (NBER) patent database (Hall, Jaffe, and Trajtenberg; 2001), which contains detailed information 
on patent applications and grants, the identifications of patent inventors and assignees, the technology class of patents, numbers of citations made and received by each patent and different measures of originality and generality of patents. This data set consists of all U.S. patents granted during the period 1963-1999 (three million patents) and all patent citations made during 19751999 (about 16 million citations). The primary sources of data for NBER are reports and announcements by the USPTO, an agency at the Department of Commerce.

The maximum term for all U.S. patents is 20 years from the date of the application. Based on the United States Patent and Trademark Office Fee Schedule, a patentee must pay a maintenance fee before the four year anniversary of the patent being granted, and subsequently after the eight year mark, and twelve year mark. The USPTO also allows patent reinstatements if the failure to pay was due to an unavoidable or unintentional delay. To show unintentional delay, the patentee has to file a reinstatement petition within twenty-four months after the six month grace period. Therefore, the sample we employ includes 282,426 patents granted in 1997, 1996 and 1995. Choosing these years enabled us to capture whether the patent was renewed at the four year points $(2001,2000$, and 1999), eight year points $(2005,2004$, and 2003) or twelve year points $(2009,2008$, and 2007) and an additional two year window within which patents can be reinstated. We limit our sample to patents filed during and after 1995 following the introduction of the Word Trading Organization's Agreement on Trade-Related Aspects of Intellectual Property Rights (TRIPs Agreement) in 1994. Under this agreement the term of all patents in the United States has to be harmonized at 20 years.

In order to verify the maintenance status of a patent we rely on the Thompson Innovation database which reports any official update on the status of the patent (INPADOC legal status) ${ }^{7}$. The INPADOC legal status data is collected by national offices that report post-issuance activities

\footnotetext{
${ }^{7}$ http://www.thomsoninnovation.com/tip-innovation/support/help/patent_fields.htm\#inpadoc_legal_status
} 
(e.g. for US patents USPTO). By looking at the INPADOC legal status we can evaluate whether maintenance fees were paid as well as the number of times they were paid. If the maintenance fees were paid three times, it means the patent completed its 20 years life cycle. Similarly two payments indicate that the patent has expired after 12 years, and one payment indicates expiry after 8 years. Finally, if a fee was never paid, we can conclude that the patent expired after 4 years.

Removing all-non-US companies and those patents belonging to government institutions narrowed the 282,426 cases from NBER down further to a sample of 201,627 patents. Additionally, the Thompson Innovation data does not report legal status for 8 percent of patents; therefore we limit our sample only to patents with reported legal status. This procedure leaves us with 186,600 patents. The third data source used in this study is the Thomson Financials SDC Platinum United States New Issues dataset (hereafter SDC), from which we obtain data on IPOs by U.S. corporations. The SDC database provides detailed information on all new issues from the beginning of 1962. We match our patent data to SDC to track the IPO dates and proceeds for patent assignees. Out of 186,600 patents (representing 21,361 assignees) about 55 percent have CUSIP identifiers that allow for matching with firm level financial data. The rest of the original sample belongs to firms that stay private, or firms that have gone public but for which Hall et al. (2001) could not find a concordance with public firm filings.

A key characteristic that represents a firm's maturity and experience is the firm's age, calculated as years from the firm's founding date. We use this variable to control for the age factor when we derive conclusions on both the timing of IPO decisions and the amount of patenting activities. To calculate the age of a firm at the time of patent application and IPO, a founding date is needed. The SDC provides founding dates for some issuers (about one third) as 
an additional feature ${ }^{8}$. As a result, the final sample includes 30,891 patents from 385 assignees (hereafter full sample).

In order to examine Hypothesis 2 we require distinguishing between firms that receive VC funding and those firms that do not. To do this, we use data on VC funding from VentureXpert (from SDC Platinum). The VC industry was very small until the late 70s (Gompers and Lerner, 1995), hence, in order to prevent selection issues, when we test hypothesis 2, we limit the sample further to firms founded after $1970^{9}$. After incorporating this data the sample falls to 6,255 patents belonging to 89 firms (hereafter the limited sample)

\section{Independent and Dependent Variables}

Our hypotheses examine the relationship between a firm's patenting activity and the timing of IPO. More specifically, we are interested in testing how proximity to IPO date affects the quantity and the quality of a firm's patenting activity. Therefore, the key independent variable in our analyses is the time difference between a patent's application year and IPO date and a Non-VC variable to control for VC investment. The dependent variables encompass various measures of the quality as well as the quantity of patenting activity around IPO dates. The dependent variables are discussed in detail here. We also control for other variables that may affect IPO decisions and the quantity or the quality of patenting activities. A detailed description of all variables (dependent, explanatory and control variables) can be found in Appendix 1.

We use five dependent variables in this study. The first variable, Number of Patents Applied, refers to the number of patents a firm in our sample has applied for in each year. We use

\footnotetext{
${ }^{8}$ To further control for reporting errors, we exclude observations with founding dates greater than IPO dates (78 observations).

${ }^{9}$ In order to check that our results are not driven by the choice of starting year we repeated the analysis separately for firms founded after 1975 and 1965. The results are qualitatively similar.
} 
a dichotomous outcome of a patent being eventually expired or not as the second dependent variable, Expired. This variable receives a value of 1 if a patent expires before 20 years ${ }^{10}$ after its grant date; and receives a value of 0 otherwise. In a logistic regression setup, we test whether the proximity of IPO date increases the likelihood that a patent applied for will expire in the future, after controlling for different firm and patent characteristics. The third variable, Expiration Category, represents a categorical outcome that a patent experiences with respect to expiration time. The Expiration Category can receive a value (an integer) between and including 1 and 4, where a value of 1 represents a patent expiration at 4 years; a value of 2 , represents expiration at 8 years; and a value of 3 , representing expiration at 12 years. A value of 4 represents no expiration prior to the 20 year term of a patent life. The patenting procedure in the U.S. market provides a setup to test Hypothesis 2 in a finer way. The holder of a patent is required to pay a renewal fee every four years in order to prevent early expiration. Thus if Hypothesis 2 holds, we should expect that a patent applied for near a firm's IPO date is more likely to expire sooner than later, that is, it belongs to a lower category than a higher category. For example a patent that is issued right before the IPO date is more likely to belong to category 1 (i.e. expires after 4 years) rather than to category 2 (expires after 8 years). We use Expiration Category in an ordered logistic framework due to the ordered nature of these categories.

We use a continuous variable, Patent Age, as another measure of a patent's utilization. Patent Age is defined as the difference between the year a patent is expired and the grant date of the patent. The previous three measures were discrete variables that are used in logistic set-ups. Using Patent Age as a continuous variable facilitates examining the robustness of the results in our discrete-variable analyses. Similar results found under both frameworks would suggest that the results are robust and independent of model specifications. Finally, we use a dichotomous

\footnotetext{
${ }^{10}$ We repeated the models for patent which have expired at 8 years.
} 
variable, Non-VC, to test Hypothesis 3. We also use this variable to test for an interaction relationship with the Expired variable. Patents belonging to firms without VC funding at the time of application receive a value of 1 for this variable and 0 otherwise.

\section{Control Variables}

We control for confounding factors that can have impact on underutilization of patents. We do so by considering two types of variables, firm characteristics and patent characteristics. Regarding firm characteristics, we control for the age of the firm at the time of the patent's application, size of IPO (million Dollar value) and the number of patents granted to the firm. We also control for patent characteristics, such as backward citation, number of claims, number of inventors, number of assignees, number of patents classes assigned to the patent and grant time calculated as time difference between applications and grant year, previously mentioned in prior literature (e.g. Trajtenberg, et al., 1997). Additionally, in order to capture differences in industries and across years we control for industry and application year fixed effects. We do so by adding 6 dummy variable referring to the 6 ISIC based industries: Chemicals, Computers and Communication, Drug and Medical, Electrical and Electronics, Mechanical and Others(apparel, furniture, etc.). Also we include dummy variables for application year of patent ${ }^{11}$.

\section{ANALYSIS}

We test our hypotheses using four analytic approaches to examine the effect of being in a pre-IPO on patenting activity (Hypothesis 1) as well as the likelihood a patent will be underutilized (Hypothesis 2), and the impact the lack of affiliation with a VC has on the likelihood of a patent being underutilized (Hypothesis 3). The first approach is a uni-variate analysis in which the

\footnotetext{
${ }^{11}$ For robustness check we also controlled for States (50 States in US) where patent were filed. Additionally, in addition to control for variation in patent classes, we controlled for number of patents that expired within same patent class (one digit patent class) of focal patent and were granted at the same year as focal patent. The results are qualitatively similar. The results are not reported and are available upon request.
} 
relationship between patenting activity and the proximity of the IPO date is demonstrated. In this approach we show how patenting activity of our sample firms changes between the five years before the IPO date and the five years post-IPO date. If Hypothesis 1 holds we expect patenting activity to increase before the IPO date. Hypothesis 2 and 3 are examined using multi-variate approaches in 3 models. The following regression models belong to each approach respectively. In all models we use two sub models. In sub-model 1, the pre-status variable is patent application 5 years prior to IPO while in the second sub-model pre-status variable is patent application 3 years prior to IPO. All sub-models have an additional interaction term between pre-IPO Status and Non-VC variables that allow us to test Hypothesis 3.

$$
\begin{aligned}
& \text { Expired }=\mathrm{A}+\mathrm{B}(\text { Pre-IPO Status })+\mathrm{C}(\text { Non-VC)+ D (Firm } \\
& \text { Characteristics })+\mathrm{E} \text { (Patent Characteristics) }
\end{aligned}
$$

$$
\begin{aligned}
& \text { Expiration Category }=\mathrm{A} 2+\mathrm{A} 3+\mathrm{A} 4+\mathrm{B} \text { (Pre-IPO Status) }+\mathrm{C} \\
& (\text { Non-VC) }+\mathrm{D} \quad(\text { Firm Characteristics })+\mathrm{E} \text { (Patent } \\
& \text { Characteristics) } \\
& \text { Patent Age = B (Pre-IPO Status) + C (Non-VC)+ D (Firm } \\
& \text { Characteristics) + E (Patent Characteristics) }
\end{aligned}
$$

In each model we examine whether proximity to the IPO date has an impact on the utilization of patents applied for, controlling for various firm and patent characteristics. The proximity to the IPO date is measured by the variable Pre-IPO Status which is a binary variable that is assigned a value of 1 if the patent is applied for within five years before IPO date, and 0 otherwise. Additionally we use a 3 year period as a robustness check. The utilization of a patent is 
measured by the likelihood of its expiration [Model (1)], the likelihood of an early expiration [Model (2)], and the age of the patent [Model (3)].

Model (1) is run under a dichotomous outcome setting (logistic regression). Model (2) is examined under a categorical outcome in which the dependent variable can have four values representing patent expirations at 4, 8, 12, or 20 years. We use an Ordered Logit framework to test this model. The dependent variable in Model (3) is continuous and we use an ordinary least square regression ${ }^{12}$ to examine this model. As a robustness check we also control for industry effects. These three models have different methodological structures, enabling us to check the validity and the robustness of our conclusions. In order to solve problems that may arise due to several observations belonging to an assignee, we cluster errors around assignee in all models.

\section{RESULTS}

Table 1 provides summary statistics for the number and percentage of underutilized patents across all industries in the full sample of 30,891 patents. The results show that the rates of expiration vary across technology fields. Of the total number of patents in our sample, 71.03 percent eventually expire due to failure to pay maintenance fees. The average number of patents granted in an industry is 5.148, with the Computer and Communication category having the largest number of grants, and Drug and Medical category holding the least number of patents. All industries have more patents expiring than those not expiring. It can be seen that the Mechanical category holds the greatest number of patents that fail to be renewed. Most patents expire at the 4 year mark.

Insert Table 1 about here

${ }^{12}$ We also used a Negative Binomial model and results are qualitatively similar. 
The percentages of patents expired after issuance is provided in Table 2. This table shows that only about 30 percent of patents issued during 1995 to 1997 are not expired. Moreover, Table 3 provides summary statistics of patent level variables. The average and median expiry years for a patent in our sample are 10.81 and 8 years respectively. All patents are given a value of 4,8 , or 12 , corresponding to the year the patent expired due to failure of paying maintenance fees, or a value of 20 meaning the patent did not expire with the assumption that if the 12 year maintenance fee is paid, then the patent will complete its life and lapse at 20 years. The table also reports statistics on the years a patent is applied for (the grant year is 1997, 1996 and 1995 for the patents in the sample) and the age of patent assignee at the time of application. The earliest and the median year a patent was applied for are respectively 1967 and 1994. The average and median time between patent application year and grant year are 1.93 and 2 years respectively, which is consistent with prior studies (Hall et al., 2001). Patents granted in 1997, 1996 and 1995 follow similar trends in expiration, with approximately 70 percent of patents expiring.

Insert Tables 2 and 3 about here

Table 4 provides descriptive statistics at the firm level. This table shows that the sample is skewed to older firms as indicated by the median founding year being 1942. The average age at which a firm files for an IPO is 48.16 years. Table 4 also shows that the average and median logarithm of the size of IPO proceeds equate to 4.89 and 4.71 respectively (equivalent to 132.93 and 111.05 million dollars). We also find that firms can vary in the number of patents they have been granted per year, from only 1 patent to the maximum of 1405 patents, with 6 being the median number of patents obtained and 34.10 the mean. Although we look at the number of patent applications per year for patents with grant years of 1997, 1996 and 1995, on average each firm applied for 21.42 patents per year with a median of 4 . 
Insert Table 4 about here

A schematic relationship between patenting activity and the proximity of the IPO date is demonstrated in Figure 1. This figure illustrates the trend in the average number of patents applied for by a firm within 5 years before and after IPO date. For this analysis we limit the firms in our sample to those firms which we have data that falls within five years pre and post their IPO date. We choose 5 years to allow for observations of patenting activity prior to IPO, assuming a firm will practice reputation-enhancing activities within the 5 years leading to IPO. The 5 years post IPO allow for enough lag time to observe any change in patenting activity once the firm has filed an IPO. Many firms in our sample have gone public before they enter into our sample, or their IPO date is within or after the 5 years prior to the last year of our sample. This leads to a sample of 2,641 patents belonging to firms which fall within five years pre and post IPO date. This sample is used to test Hypothesis 1. Figure 1 shows an increase in patenting activity before the IPO date and the subsequent decline after IPO. Peak activity is at minus 2 years, which is particularly interesting given that the average time elapsed between the years a patent is applied for and the time it is granted is 2.09 years (see Table 3). A simple t-test verifies the difference on mean number of patents 5 years prior to IPO (85.23) and 5 years after IPO (76.10). The difference is statistically significant at a 1 percent level. These findings suggest that firms may be intentionally timing their applications with intended IPO dates bearing in mind that the average patent takes about two years after application date to be granted. These findings support Hypothesis 1.

Insert Figure 1 about here 
Table 5 reports correlations between dependent, independent and control variables in model (1). These variables are used in the multi-variate analyses to follow.

\section{Insert Table 5 about here}

To examine Hypothesis 2, we first study the distribution of expired patents with respect to the proximity of patents' issue dates and their assignees' IPO dates. Table 6 shows that while 84.26 percent of patents filed within 5 years prior to IPO expire, this number is much less $(68.68$ percent) for those patents that do not. A proportion test and Pearson's chi square test verifies that two groups are distributed significantly differently (p-value of 0.000). Tables 7,8 and 9 present the results of running Models (1), (2) and (3) respectively. Each table provides two groups of results (or two sub-models). Results for each sub-model differ from each other in the choice of the main independent variable, which is a dummy variable indicating when the patent application occurred from the firm's IPO date. In sub-sample 1 this dummy variable is assigned a value of 1 if the application has happened within 5 years prior to IPO date and in Sub-model 2 this dummy variable is assigned a value of 1 if the application has happened within 3 years prior to IPO date. Our results are robust to different timeframes we consider for this dummy variable.

Insert Table 6 about here

Table 7 demonstrates that firms that are about to IPO are more likely to apply for a patent that will expire before 20 years after the application year. The results for each sub-sample are presented in three columns differing in the choice of control variables used to test Hypotheses 2 and 3. The first two columns (columns 1 and 2 in sub-sample 1 and 4 and 5 in sub-sample 2) provide results on hypothesis 2 and the last columns (column 3 in sub-sample 1 and column 6 in 
sub-sample 2) provide results on hypothesis 3. Columns 1 and 4 report the result for the full sample while column 2 and 5 repeat the analysis on the limited sample. The coefficient is significantly larger for the limited sample (which includes firms founded after 1970). This provides further evidence on the signaling nature of patents. Since younger firms have higher information asymmetries with market participants, the marginal effect of a signal is larger for them in comparison with more mature and well established firms. Moreover, the coefficients for the same variable in columns 2 and 5, where a non-vc dummy is included, are 4.02 and 3.82, both significant at a 1 percent level. This implies a 37 percent and a 36 percent increase in the probability of expiration when a patent is filed closer to issuer's IPO date. These results provide support for Hypothesis 2.

Insert Table 7 about here

Columns 3 and 6 in Table 7 report the results for Hypothesis 3. Consistent with Hypothesis 3, we find a positive and significant coefficient on the interaction terms, Non-VC and pre-IPO status. This verifies that the magnitude of the effect of being near the IPO time on likelihood of expiration is greater for firms that are not associated with a VC. As VCs can play a significant role as certifying agents in the IPO market (Meggison and Weise, 1995), these results suggest that firms which are not associated with a VC are more likely to use patents as signals of quality to outside investors near IPO time. The coefficients in columns 3 and 6 (sub-models 1 and 2) respectively are 3.81 and 3.62 and are both statistically significant at 5 percent. These coefficients represent the change in the log odds of patent expiry as a non VC-backed issuer approaches the IPO date. The result can be interpreted as a 34 percent and a 33 percent higher probability of patent expiration if the issuer is a non-VC backed firm . 
Table 7 also shows other interesting results. For instance, patents with more International Patent classes (IPCs) are more likely to expire. This result is statistically significant. The number of claims made adversely affects the likelihood of being expired. The number of claims is indicative of the scope or width of an invention (Hall et al., 2001). Patents with a higher number of claims are generally more expensive to apply for, and therefore can indirectly measure the importance of the patent for the assignee. Finally the models control for year and industry fixed effect and error terms are clustered around assignees to avoid any bias that might be created from differences in patenting activities across different industries and firms that may be applying for more than one patent during the sample period.

Insert Table 8 about here

Table 8 also provides additional insight into the patenting activity relative to Table 7 . The nature of our data facilitates using a finer technique, known as the proportional odds technique or an ordered logistic model. The dependent variable is a categorical variable. It is assigned a value of 4 if a patent never expires. It is equal to a value of 3,2 and 1 respectively if the patent expires at 12,8 or 4 years. The interpretation of coefficients in this technique is similar to the interpretation of an ordinary logistic regression - except there are three transitions estimated here versus one - as there would be with a dichotomous dependent variable. A patent applicant being close to the time of IPO decreases the likelihood of the patent expiration at a higher level. In other words it is more likely for a patent to expire in 4 years versus in 8 years, and similarly in 8 years versus 12 years and finally in 12 years versus 20 years. The intercepts can then be used to calculate what the predicted probability is for a patent, with a given set of firm-patent characteristics, being in a particular expiration category. 
Table 8 presents the results of Model (2) in an ordered logistic regression framework where results and coefficients support the results found in Table 6 . In column 1 the coefficient is negative, as expected, and not statistically significant ( $p$-value 0.11 ). However, the addition of the interaction term, makes it statistically significant at 1 percent level, thus strongly supporting Hypothesis 3. The results suggest that being close to IPO matters specifically when the firm is not VC-affiliated. In other words, firms are more likely to use patents as reputation signals when a third-party certification is lacking. The control variable, assignee count, has an insignificant coefficient in Table 7; however in Table 8 the coefficient is significant and adversely related to the dependent variable in this model.

Insert Table 9 about here

Finally, Table 9 presents the results of an Ordinary Least Square regression used to test Model (3). Supporting our previous results, this model demonstrates that firms apply for patents that expire faster when they are close to their IPO date. Table 9 illustrates results for Model (3) under 2 different sub-models. The results overall support our previous findings.

\section{DISCUSSION AND CONCLUSION}

Overall, the results of this study show support for the argument that when firms patent for the purpose of building a reputation, there is a greater likelihood for these patents to eventually be rendered underutilized. We find a significant and positive relationship between the likelihood of patents expiring due to lack of maintenance fee payments and the time to IPO. We also find that patents associated with firms which are not venture capital backed, are more likely to expire.

Patents continue to act as indicators of firm innovation activity (Heeley, Matusik, and Jain, 2007). Patent data offers a unique combination of detail and coverage which make them 
particularly well suited for innovation related studies (Lanjouw, Pakes and Putnam, 1998). Patent data is available for all firms and individuals for a long period of time, and whereas R\&D expenditure data have been the most commonly used alternative, they are more related to inputs into the innovative process than to outputs (Lanjouw et al., 1998). Research typically relied exclusively on simple patent counts as indicators of some sort of innovative output (see Griliches, 1990 for a review). However, it is now recognized that innovations vary immensly in their importance, impact, and economic value (Hall et al., 2001, 2005) and thus the patent count method often runs into difficulties. Schankerman and Pakes (1986) challenged previous studies that showing that the patent/R\&D ratio declined rapidly over time in most Western countries, indicating a period of 'technological exhaustion' (Lanjouw et al., 1998). They compared aggregate patent count indices to their estimated patent value inidces for each of the UK, France and Germany for the period of 1955 to 1975 and concluded that '...one cannot draw inferences on changes in the value of cohorts of patents during this period from changes in the quantity of patents, for there have been large (and laregely offsetting) changes in the 'quality' (or mean values) of patents'. Other studies followed showing that variations in patents exist. For example, decreases in patent counts were found to be partially offset by increases in the average value of the patent (Pakes and Simpson, 1989; Schankerman, 1998) and patents from different ISIC industry categories have different value distributions as well (Pakes and Simpson, 1989). Lanjouw, Pakes and Putnam (413:1998) state 'indeed one of the longest lasting debates in the history of economic measurement has been whether the noise and the biases in patent count measures can be made small enough to make patent counts useful measures of innovative output in economic studies'. This article reiterates the problems faced with the use of patent counts and the call for the use of both renewal and application data to develop a weighted patent count measure (Lanjouw et al., 1998; Lanjouw, 1998; Pakes, 1986; Pakes and Schankerman, 1984). 
This study contributes to the patent literature in a number of ways. First, this study expands the literature on why firms patent by underscoring the role that reputation plays in whether a firm is likely to use patents to signal value to potential investors. In doing so, this study challenges the notion that patents reflect a firms actual innovative potential and suggests that often patents are never commercialized. As Jaffe notes, this finding suggests that patenting has evolved from a system to protect innovation to a system of illusionary signaling that may often not be indicative of true innovative capacity. The information contained in a patent provides little information about the ability of the firm to extract value from the invention unless the reader of the patent is 'skilled in the art' (Heeley, Matusik, and Jain, 2007). Although investors look for the quality and quantity of patents in a potential firm, the reality is that often the content of the patent does not provide usable information to the majority of members of the investment community (Heeley et al., 2007).

A second contribution of this study stems from its focus on the life cycle of patents. Particularly, as there is very little work on underutilized patents (see Moore, 2005 for an exception), this study offers a unique opportunity to track the creation and evolution of patents that fail to commercialize.

Third, whereas previous work, for the most part, takes a cross-sectional approach by examining the economic motives for whether a firm chooses to patent or not, this study contributes to the literature and extends this stream of work by adopting a longitudinal perspective that explores the fate of patents once they have been granted.

Our study has some limitations that may also present fruitful avenues for future research. One limitation of this study is that it focuses on signaling at the IPO period. Although the IPO context is a very relevant event for this study, there are other events in the life of a firm that could be interesting to investigate and perhaps validate the findings of this study. It is possible that once 
firms IPO R\&D direction may change and thus patents that were once of interest to the firm are no longer. Additional research that investigates other reputation enhancing events could provide additional insight as to whether underutilization is a reflection of the intended purpose of the patent as a signal or a change in $\mathrm{R} \& \mathrm{D}$ focus. Second, of great interest are those patents that expire at 12 years. Why would a firm let a patent go after 12 years of maintenance? It is one thing to hold a patent for 4 years, and pay one set of fees and decide that the cost to maintain it are greater than its potential worth, but as the results indicate, there are many patents that only expire at the 12 year mark. Third, this study looked at only one of the many strategic uses for patents. Others that have been cited in the literature and in this article include the use of patents to prevent litigation, to build fences, and blocking competitors. Similar studies to this one could be designed to investigate the fate of those patents used for these strategic reasons. Finally, this research used secondary data. An important direction for future studies would be to complement a large-scale quantitative study with qualitative research analyzing decision making at the patent level. A qualitative study that looks at both the decision makers in a firm and their patenting motives as well as the investors valuating these companies would likely provide rich process data that would offer additional depth and breadth. A complementary qualitative study would also help address the limitations previously discussed.

Beyond research implications, this study also offers some practical implications from a management, investor, and policy perspective. Managers need to balance the need to show investors they are innovative and have a strong patent portfolio that protects their innovations, with the need to not be sitting on innovations that may be of value to a company through commercialization means or licensing means. From an investor's perspective, investors need to realize that the quantity of patents may not be a good indicator of how innovative a company is. Although patents have a history of being used as proxies for innovation, we see the numbers of 
patents increasing exponentially, but commercialized innovations on a decline (Gold, 2008). There is a need to revisit the innovation construct in relation to patents. 


\section{REFERENCES}

Basdeo, D. K., Smith, K. G., Grimm, C. M., Rindova, V. P., and Derfus, P. J. 2006. The impact of market actions on firm reputation. Strategic Management Journal 27: 1205-1219.

Baum, J. A.C. and Silverman, B. S. 2004. Picking winners or building them? Alliance, intellectual and human capital as selection criteria in venturing financing and performance of biotechnology startups. Journal of Business Venturing 19(3): 411-436.

Beatty, R. P. 1989. Auditor reputation and the pricing of initial public offerings. Accounting Review 64: 693-709.

Bhattacharya, S. 1979. Imperfect information, divident policy, and the 'bird in the hand' fallacy. Bell Journal of Economics and Management Science 10: 259-270.

Blind, K., Edler, J., Frietsch, R. and Schmoch, U. 2006. Motives to patent: Empirical evidence from Germany. Research Policy 35(5): 655-672.

Boot, A. W. A., Greenbaum, S. I., and Thakor, A. V. 1993. Reputation and discresion in financial contracting." American Economic Review 83: 1165-1183

Brown, B. and Perry, S. 1994. Removing the financial performance halo from Fortune's 'Most Admired' companies. Academy of Management Journal 37(5): 1347-1359.

Bygrave, W.D. and Timmons, J.A. 1992. Venture Capital At The Crossroads. Harvard Business School Press: Boston, MA.

Carter, R. B., Dark, F. H., and Singh, A. K. . 1998. Underwriter reputation, initial returns, and the long-run performance of IPO stocks. Journal of Finance 53: 285-311.

Carter, R. B., and Manaster, S. 1990. Initial public offerings and underwriter reputation. Journal of Finance 45: 1045-1067.

Certo, S. T. 2003. Influencing initial public offering investors with prestige: Signaling with board structures. Academy of Management Review 28(3): 432-446.

Clark, B. H., and Montgomery, D. B. 1998. Deterrence, reputations and competitive cognition. Management Science 44(1): 62-82.

Cohen, W. M., Nelson, R. R., and Walsh, J. P. 2000. Protecting their Intellectual Assets: Appropriability Conditions and Why U.S. Manufacturing Firms Patent (or Not). National Bureau of Economic Research.

Deephouse, D. L. 2000. Media reputation as a strategic resource: An integration of mass communication and resource-based theories. Journal of Management 26(6): 1091-1112.

Dierickx, I., and Cool, K. 1989. Asset stock accumulation and sustainability of competitive advantage. Management Science, 35(12): 1504-1511.

Ferrier, W. J. 1997. 'Tough talk' and market leaders: the role of overt signaling and reputationbuilding behaviors in sustaining industry dominance. Corporate Reputation Review 1: 98103.

Field, L. C and Karpoff, J. M. 2002. Takeover defenses of IPO firms. The Journal of Finance 57(5): 1857-1889.

Flanagan, D. J. and O'Shaughnessy, K. C. 2005. The effects of layoffs on firm reputation. Journal of Management 31(3): 445-463.

Fombrun, C., and Rindova, V. "Reputation Management in global 1000 firms: a benchmarking study." Corporate Reputation Review, Vol. 1(1998), pp. 205-211.

Fombrun, C., and Shanley, M. 1990. What's in a name? Reputation building and corporate strategy. Academy of Management Journal 33(2): 233-258.

Gambardella, A., Giuri, P., and Mariani, M. 2008. The Value of European Patents: Evidence from a Survey of European Inventors. European Management Review 5: 69-84. 
Gold, R. 2008. Toward a new era of intellectual property: from confrontation to negotiation. International Expert Group on Biotechnology, Montreal, Canada.

Gompers, P. and Lerner, J., 1999. The Venture Capital Cycle. MIT Press, Cambridge, MA.

Gorman, M. and Sahlman, W.A. 1989. What do venture capitalists do. Journal of Business Venturing 4(4): 231-248.

Griliches, Z. 1990. Patent statistics as economic indicators: A survey. Journal of Economic Literature 28: 1661-1707.

Haeussler, C., Harhoff, D., and Muller, E. 2009. To be financed or not - the role of patents for venture capital financing. Electronic Library: http://papers.ssrn.com.

Hall, R. 1992. The strategic analysis of intangible resources. Strategic Management Journal 13(2): 135-144.

Hall, B. H., Jaffe, A. B., and Trajtenberg, M. 2001. The NBER patent citations data file: lessons, insights, and methodological tools. National Bureau of Economics Research.

Hall, B. H., Jaffe, A., and Trajtenberg, M. 2005. Market Value and Patent Citations. Rand Journal of Economics Spring.

Hall, B. H., and Ziedonis, R. H. 2001. The determinants of patenting in the U.S. semiconductor industry, 1980-1994. Rand Journal of Economics 32: 101-128.

Heeley, M. B., Matusik, S. F., and Jain, N. 2007. Innovation, appropriability, and the underpricing of initial public offerings. Academy of Management Journal 50(1): 209-225.

Heil, O., and Robertson, T. 1991. Toward a theory of competitive market signaling: a research agenda. Strategic Management Journal 12(6): 403-418.

Higgins, M. C., and Gulati, R. 2006. Stacking the deck: The effects of top management backgrounds on investor decisions. Strategic Management Journal 27: 1-25.

Hsu, D.H., 2004. What do entrepreneurs pay for venture capital affiliation? Journal of Finance 59(4): 1805-1844.

Hsu, D. H. and Ziedonis, R. H. 2008. Patents as Quality Signals for Entrepreneurial Ventures. In Best Paper Proceedings of Academy of Management, Anaheim, CA. Available at: http://annualmeeting.aomonline.org/2008/index.php?option=com_docman\&task=cat_view \&gid=59\&Itemid=30.

Hsu, D. H. and Ziedonis, R. H., 2013. Resources as dual sources of advantage: Implications for valuing entrepreneurial-firm patents. Strategic Management Journal 34: 761-781.

Lanjouw, J. O. 1998. Patent protection in the shadow of infringement: Simulation estimations of patent value. The Review of Economic Studies 65: 671-710.

Lanjouw, J. O., Pakes, A., and Putnam, J. 1998. How to count patents and value intellectual property: The uses of patent renewal and application data. The Journal of Industrial Economics 46(4): 405 - 432.

Lemley, M. A. 2000. Reconceiving Patents in the Age of Venture Capital. Journal of Small and Emerging Business Law 4(1): 137-148.

Lemley, M. A. 2001. Rational Ignorance at the Patent Office. Northwestern University Law Review 95(4): 1497-1532.

Lemley, M. A., and Shapiro, C. 2005. Probabilistic Patents. The Journal of Economic Perspectives 19(2): 75-98.

Long, C. Patent Signals. The University of Chicago Law Review 69(2): 625-679.

Mann, R. J. and Sager, T. W. 2007. Patents, venture capital, and software start-ups. Research Policy 36(2): 193-208.

March, J. and Simon, H. 1958 Organizations. John Wiley \& Sons, New York, NY. 
Megginson, W. L., and Weiss, K. A. 1991. Venture capitalist certification in initial public offerings. Journal of Finance 46: 879-903.

Moore, K. A. 2005. Worthless Patents. Berkeley Technology Law Journal 20: 1521-1552.

Nadeau, P. 2010. Venture capital investment selection: do patents attract investors? Strategic Change 19(7/8): 325-342.

Pakes, A. and Schankerman, M. 1984. The rate of obsolescence of patents, research gestation lags, and the private rate of return to research resources, In $R \& D$, Patents and Productivity, Griliches Z (ed.) The University of Chicago Press, NBER Conference Series. Chicago.

Pakes, A. and Simpson, M. 1989. Patent renewal data. Brookings Papers on Economic Activity: Microeconomics: $331-410$.

Pfeffer, J. and Salancik, G. 1978. The external control of organizations: A resource dependence perspective. Harper \& Row, New York, NY.

Pisano, G. 1997. The Development Factory. Harvard Business School Press, Boston, MA.

Rao, H. 1994. The social construction of reputation: certification contests, legitimation, and the survival of organizations in the American automobile industry: 1895-1912. Strategic Management Journal Winter Special Issue (15): 29-44.

Reuber, A. R., \& Fischer, E. 2009. Signaling reputation in international online markets. Strategic Entrepreneurship Journal 3: 369-386.

Rindova, V. P., and Fombrun, C. 1999. Constructing competitive advantage: the role of firmconstituent interactions. Strategic Management Journal 20(8): 691-710.

Roberts, P. W. and Dowling, G. R. 2002. Corporate reputation and sustained financial performance. Strategic Management Journal 23(12): 1077-1093.

Ross, S. A. 1977. The determinants of financial structure: The incentive signaling approach. Bell Journal of Economics 8: 23-40.

Sapienza, H.J., Manigart, S., Vermier, W. 1996. Venture capitalist governance and value added in four countries. Journal of Business Venturing 11(6) 439 - 469.

Schankerman, M. 1998. How valuable is patent protection: Estimates by technology fields. The RAND Journal of Economics 29(1): 77-107.

Schankerman, M. \& Pakes, A. 1986. Estimates of value of patent rights in European countries during the post-1950 period. The Economic Journal 96: 1052-1076.

Serrano, C. J. 2010. The dynamics of the transfer and renewal of patents. RAND Journal of Economics 41(4): 686-708.

Sichelman, T. 2010. Commercializing Patents. Standford Law Review 62(2): 341-413.

Shapiro, C. 2001. Navigating the Patent Thicket: Cross-Licenses, Patent Pools, and StandardSetting. In Innovation Policy and the Economy, Jaffe, A., Lerner, J. and Scott Stern (eds.), National Bureau of Economics.

Sorensen, M., 2007. How smart is smart money? A two-sided matching model of venture capital. Journal of Finance 62(6).

Spence, S. 1973. Job market signaling. Quarterly Journal of Economics 87: 355-379.

Stinchcombe, A. L. 1965. Social structures and organizations. In Handbook of Organizations March JG (ed.), 142-193. Chicago: Rand McNally.

TRAJTENBERG, M., HENDERSON, R. \& JAFFE, A., 1997. University Versus Corporate Patents: A Window On The Basicness Of Invention. Economics of Innovation and New Technology, 5(1): 19-50.

Ueda, M., 2004. Banks versus venture capital: Project evaluation, screening, and expropriation. Journal of Finance 59(2): 601-621.

U.S. House of Representative Oversight Hearing on the Patent System, (February 15, 2007). 
USPTO Annual Reports. 2003. www.uspto.gove

Weigelt, K., \& Camerer, C. 1988. Reputation and coporate strategy: a review of recent theory and applications. Strategic Management Journal 9(5): 443-454. 
Table 1. Summary of expired patents by industry

\begin{tabular}{lcccccc}
\hline & \# Patents & Expired (\%) & Exp at 4 yrs (\%) & Exp at 8 yrs (\%) & Exp at 12 yrs (\%) & Did not expire (\%) \\
\hline Chem $^{\mathbf{a}}$ & 3,700 & $2,704(73.08)$ & $1,225(33.11)$ & $856(23.14)$ & $623(16.84)$ & $996(26.92)$ \\
$\mathbf{C \& C}^{\mathbf{b}}$ & 9,671 & $6,432(66.51)$ & $3,366(34.81)$ & $1,354(14.00)$ & $1,712(17.70)$ & $3,239(33.49)$ \\
$\mathbf{D \& M}^{\mathbf{c}}$ & 1,400 & $807(57.64)$ & $382(27.29)$ & $271(19.36)$ & $154(11.00)$ & $593(42.36)$ \\
$\mathbf{E \& E}^{\mathbf{d}}$ & 8,303 & $5,971(71.91)$ & $2,893(34.84)$ & $1,617(19.47)$ & $1,461(17.60)$ & $2,332(28.09)$ \\
Mech $^{\mathbf{e}}$ & 5,036 & $4,037(80.16)$ & $1,749(34.73)$ & $1,326(26.33)$ & $962(19.10)$ & $999(19.84)$ \\
Other $^{\mathbf{r}}$ & 2,781 & $1,991(71.59)$ & $931(33.48)$ & $584(21.00)$ & $476(17.12)$ & $790(28.41)$ \\
\hline Total & 30,891 & $21,942(71.03)$ & $10,546(34.14)$ & $6,008(19.45)$ & $5,388(17.44)$ & $8,949(28.97$ \\
\hline
\end{tabular}

${ }^{\mathrm{a}}$ Chemical, ${ }^{\mathrm{b}}$ Computers and Communication, ${ }^{\mathrm{c}}$ Drugs and Medical, ${ }^{\mathrm{d}}$ Electrical and Electronics, ${ }^{\mathrm{e}}$ Mechanical, ${ }^{\mathrm{f}}$ Other (apparel, furniture, etc).

Table 2. Summary of expired patents by grant year

\begin{tabular}{lcccc}
\hline & & Grant Year & \\
\hline & 1995 & 1996 & 1997 & Total \\
Not expired (\%) & $2,639(26.04)$ & $3,115(29.12)$ & $3,195(31.75)$ & 8,949 \\
Expired (\%) & $7,494(73.96)$ & $7,581(70.88)$ & $6,867(68.25)$ & 21,942 \\
\hline Total & 10,133 & 10,696 & 10,062 & 30,891 \\
\hline
\end{tabular}




\section{Table 3. Descriptive statistics of patent level variables}

\begin{tabular}{|c|c|c|c|c|c|c|c|}
\hline Variable & Mean & Std Dev & Min & 25th Pctl & Median & 75th Pctl & $\operatorname{Max}$ \\
\hline Patent Age (Year Expired) & 10.81 & 6.48 & 4 & 4 & 8 & 20 & 20 \\
\hline Patent Application Year & 1994 & 1.26 & 1967 & 1993 & 1994 & 1995 & 1997 \\
\hline Time Elapsed from Patent Application to Grant & 1.93 & 1.03 & 0 & 0 & 2 & 2 & 29 \\
\hline Number of Claims & 16.03 & 11.97 & 1 & 8 & 14 & 20 & 200 \\
\hline Citations Made & 12.15 & 11.73 & 0 & 5 & 9 & 15 & 182 \\
\hline Number of Inventors & 2.32 & 1.43 & 1 & 1 & 2 & 16 & 20 \\
\hline Number of Assignees & 1.00 & 0.10 & 1 & 1 & 1 & 4 & 4 \\
\hline Number of IPC & 1.78 & 1.00 & 1 & 1 & 1 & 2 & 8 \\
\hline Assignee Age & 54.31 & 27.47 & 0 & 26 & 64 & 78 & 95 \\
\hline
\end{tabular}

$N=30,891$

Table 4. Descriptive statistics of firm level variables

\begin{tabular}{|c|c|c|c|c|c|c|c|}
\hline Variable & Mean & Std Dev & Min & 25th Pctl & Median & 75th Pctl & $\operatorname{Max}$ \\
\hline Year Patent Assignee Founded & 1942.68 & 27.66 & 1901 & 1919 & 1942 & 1970 & 1995 \\
\hline IPO Year & 1990.84 & 9.79 & 1970 & 1983 & 1990 & 1997 & 2012 \\
\hline Assignee's Age at IPO Year & 48.16 & 30.64 & 0 & 14 & 55.5 & 75 & 109 \\
\hline IPO Size \$m (log) & 4.89 & 1.35 & -0.005 & 3.99 & 4.71 & 6.23 & 7.66 \\
\hline Number of Patents Granted per year & 34.09 & 103.92 & 1 & 2 & 6 & 605 & 1405 \\
\hline $\begin{array}{l}\text { Number of Patents application per year } \\
\text { (granted on 1997, 1996, 1995) }\end{array}$ & 21.42 & 73.11 & 1 & 2 & 4 & 560 & 1435 \\
\hline
\end{tabular}


Table 5. Correlation between main dependent (expired=1 for underutilized patents), independent and control variables

\begin{tabular}{|c|c|c|c|c|c|c|c|c|c|c|c|c|}
\hline & (1) & (2) & (3) & (4) & $(5)$ & (6) & (7) & (8) & (8) & (10) & (11) & (12) \\
\hline Expired & 1 & & & & & & & & & & & \\
\hline Application was in $[-5,0]$ of IPO & 0.2518 & 1 & & & & & & & & & & \\
\hline Non-VC & 0.1602 & 0.5052 & 1 & & & & & & & & & \\
\hline Time Elapsed from Patent Application to Grant & -0.0248 & 0.0318 & -0.0375 & 1 & & & & & & & & \\
\hline IPO Size & 0.0156 & 0.0355 & 0.0007 & 0.032 & 1 & & & & & & & \\
\hline Age of firm at the Time of Application & -0.185 & -0.3905 & -0.5161 & -0.1267 & 0.3685 & 1 & & & & & & \\
\hline Number of Inventors & -0.0328 & 0.0357 & -0.0453 & 0.0572 & 0.2242 & 0.0976 & 1 & & & & & \\
\hline Number of IPC & 0.0514 & -0.0332 & -0.0326 & 0.0766 & 0.2733 & 0.0618 & 0.112 & 1 & & & & \\
\hline Assignee Count & 0.0131 & -0.0079 & -0.0155 & 0.0484 & -0.0258 & -0.0143 & 0.0275 & 0.0232 & 1 & & & \\
\hline Citations Made & 0.0292 & 0.0227 & 0.0184 & 0.0121 & -0.0011 & -0.0369 & 0.1152 & 0.0301 & 0.0066 & 1 & & \\
\hline Number of Claims & -0.147 & -0.0892 & -0.0234 & 0.0538 & -0.1137 & -0.0045 & 0.0261 & -0.0123 & 0.0268 & 0.0489 & 1 & \\
\hline Number of Patents & -0.0768 & 0.054 & -0.1135 & -0.1372 & 0.2001 & 0.2875 & 0.0104 & -0.065 & 0.0126 & -0.0661 & 0.0247 & 1 \\
\hline
\end{tabular}

Table 6. Distribution of expired patent and time to IPO

\begin{tabular}{|c|c|c|c|}
\hline & \multicolumn{2}{|c|}{ Application was in $[-5,0]$ of IPO } & \\
\hline expired & 0 & 1 & Total \\
\hline 0 & $8216(31.32)$ & $733(15.74)$ & 8,949 \\
\hline 1 & $18019(68.68)$ & $3923(84.26)$ & 21,942 \\
\hline Total & 26,235 & 4,656 & 30,891 \\
\hline
\end{tabular}

$N=30,891$ 
Table 7. Patent-level analysis: Relationship between time to IPO and likelihood of patent expiry

\begin{tabular}{|c|c|c|c|c|c|c|}
\hline \multirow{3}{*}{ Application was in $[-5,0]$ of IPO } & \multicolumn{3}{|c|}{ Sub-Model 1} & \multicolumn{3}{|c|}{ Sub-Model 2} \\
\hline & (1) & (2) & (3) & (4) & (5) & (6) \\
\hline & $\begin{array}{l}\mathbf{0 . 8 2 7 0} * \\
(\mathbf{0 . 4 5 5 2 )}\end{array}$ & $\begin{array}{l}4.0228 * * * \\
(1.1767)\end{array}$ & $\begin{array}{l}1.2793 * * * \\
(0.4531)\end{array}$ & & & \\
\hline Application was in $[-3,0]$ of IPO & & & & $\begin{array}{l}0.9393 * * \\
(0.4572)\end{array}$ & $\begin{array}{l}\text { 3.8178*** } \\
(1.1093)\end{array}$ & $\begin{array}{c}1.2596 * * * \\
(0.4600)\end{array}$ \\
\hline Non-VC & & $\begin{array}{l}-0.7146 \\
(0.7912)\end{array}$ & $\begin{array}{l}-0.7790 \\
(0.7730)\end{array}$ & & $\begin{array}{l}-0.5938 \\
(0.7952)\end{array}$ & $\begin{array}{l}-0.6533 \\
(0.7783)\end{array}$ \\
\hline IPO_5yr*NON-VC & & & $\begin{array}{l}3.8170 * * \\
(1.5466)\end{array}$ & & & \\
\hline IPO_3yr*NON-VC & & & & & & $\begin{array}{c}3.6185 \\
(1.5306)^{* *}\end{array}$ \\
\hline Time Elapsed from Patent Application to & 0.0251 & -0.0417 & -0.0307 & 0.0220 & -0.0304 & -0.0186 \\
\hline & $(0.0410)$ & $(0.0914)$ & $(0.0936)$ & $(0.0398)$ & $(0.0977)$ & $(0.1002)$ \\
\hline IPO Size & & $\begin{array}{c}0.0004 \\
(0.0007)\end{array}$ & $\begin{array}{c}0.0004 \\
(0.0007)\end{array}$ & & $\begin{array}{c}0.0005 \\
(0.0007)\end{array}$ & $\begin{array}{c}0.0005 \\
(0.0007)\end{array}$ \\
\hline Age of firm at the Time of Application & $\begin{array}{c}0.0100 \\
(0.0062)\end{array}$ & $\begin{array}{l}-0.0468 \\
(0.0658)\end{array}$ & $\begin{array}{l}-0.0436 \\
(0.0655)\end{array}$ & $\begin{array}{c}0.0105 * \\
(0.0063)\end{array}$ & $\begin{array}{l}-0.0515 \\
(0.0668)\end{array}$ & $\begin{array}{l}-0.0484 \\
(0.0664)\end{array}$ \\
\hline Number of Inventors & $\begin{array}{l}-0.0045 \\
(0.0239)\end{array}$ & $\begin{array}{l}-0.0358 \\
(0.0341)\end{array}$ & $\begin{array}{l}-0.0355 \\
(0.0338)\end{array}$ & $\begin{array}{l}-0.0060 \\
(0.0237)\end{array}$ & $\begin{array}{l}-0.0352 \\
(0.0343)\end{array}$ & $\begin{array}{l}-0.0348 \\
(0.0340)\end{array}$ \\
\hline Number of IPC & $\begin{array}{c}0.0453 \\
(0.0387)\end{array}$ & $\begin{array}{c}\mathbf{0 . 2 1 5 1} * * * \\
(0.0807)\end{array}$ & $\begin{array}{c}\text { 0.2181*** } \\
(0.0809)\end{array}$ & $\begin{array}{c}0.0401 \\
(0.0389)\end{array}$ & $\begin{array}{c}\mathbf{0 . 2 0 8 7} * * * \\
(0.0809)\end{array}$ & $\begin{array}{c}0.2114 * * * \\
(0.0809)\end{array}$ \\
\hline Assignee Count & $\begin{array}{c}\mathbf{0 . 6 3 1 8} * * * \\
(0.2428)\end{array}$ & $\begin{array}{r}0.9260 \\
(0.6378)\end{array}$ & $\begin{array}{c}0.9281 \\
(0.6404)\end{array}$ & $\begin{array}{l}0.6246 * * * \\
(0.2372)\end{array}$ & $\begin{array}{r}0.9100 \\
(0.6342)\end{array}$ & $\begin{array}{r}0.9110 \\
(0.6366)\end{array}$ \\
\hline Citations Made & $\begin{array}{l}-0.0004 \\
(0.0038)\end{array}$ & $\begin{array}{c}0.0061 \\
(0.0072)\end{array}$ & $\begin{array}{c}0.0063 \\
(0.0073)\end{array}$ & $\begin{array}{l}-0.0004 \\
(0.0037)\end{array}$ & $\begin{array}{c}0.0058 \\
(0.0072)\end{array}$ & $\begin{array}{c}0.0061 \\
(0.0073)\end{array}$ \\
\hline Number of Claims & $\begin{array}{c}\mathbf{- 0 . 0 0 7 9} * * \\
(0.0036)\end{array}$ & $\begin{array}{c}\mathbf{- 0 . 0 1 8 7} * * * \\
(0.0059)\end{array}$ & $\begin{array}{c}\mathbf{- 0 . 0 1 8 6} * * * \\
(0.0059)\end{array}$ & $\begin{array}{c}-0.0082 * * \\
(0.0036)\end{array}$ & $\begin{array}{c}\mathbf{- 0 . 0 1 9 3} * * * \\
(0.0059)\end{array}$ & $\begin{array}{c}\mathbf{- 0 . 0 1 9 3} * * * \\
(0.0060)\end{array}$ \\
\hline Number of Patents & $\begin{array}{c}\mathbf{0 . 0 0 1 0} * * \\
(0.0005)\end{array}$ & $\begin{array}{l}-0.0033 \\
(0.0045)\end{array}$ & $\begin{array}{l}-0.0036 \\
(0.0044)\end{array}$ & $\begin{array}{l}0.0011 * * \\
(0.0005)\end{array}$ & $\begin{array}{l}-0.0032 \\
(0.0045)\end{array}$ & $\begin{array}{l}-0.0035 \\
(0.0044)\end{array}$ \\
\hline Grant year dummies & YES & YES & YES & YES & YES & YES \\
\hline Industry Fixed effect & YES & YES & YES & YES & YES & YES \\
\hline Constant & $\begin{array}{l}-0.5829 \\
(0.5025)\end{array}$ & $\begin{array}{r}1.6360 \\
(1.6143)\end{array}$ & $\begin{array}{c}1.6054 \\
(1.6156)\end{array}$ & $\begin{array}{c}-0.5728 \\
(0.4996)\end{array}$ & $\begin{array}{c}1.6447 \\
(1.6187)\end{array}$ & $\begin{array}{c}1.6111 \\
(1.6190)\end{array}$ \\
\hline $\mathbf{N}$ & 30,891 & 6,255 & 6,255 & 30,891 & 6,255 & 6,255 \\
\hline
\end{tabular}


Table 8. Patent-level analysis: Relationship between time to IPO and patent life category

\begin{tabular}{|c|c|c|c|c|c|c|}
\hline & \multicolumn{3}{|c|}{ Sub-Model 1} & \multicolumn{3}{|c|}{ Sub-Model 2} \\
\hline & (1) & (2) & (3) & (4) & (5) & $(60$ \\
\hline Application was in $[-5,0]$ of IPO & $\begin{array}{l}-0.4752 \\
(0.2991)\end{array}$ & $\begin{array}{c}-2.2531 * * * \\
(0.6815)\end{array}$ & $\begin{array}{l}-0.4350 \\
(0.3153)\end{array}$ & & & \\
\hline Application was in $[-3,0]$ of IPO & & & & $\begin{array}{l}\mathbf{- 0 . 6 0 8 1 *} \\
(0.3425)\end{array}$ & $\begin{array}{c}-1.9909 * * * \\
(0.5930)\end{array}$ & $\begin{array}{l}-0.4115 \\
(0.3260)\end{array}$ \\
\hline Non-VC & & $\begin{array}{c}0.2103 \\
(0.6180)\end{array}$ & $\begin{array}{c}0.4891 \\
(0.6197)\end{array}$ & & $\begin{array}{c}0.0407 \\
(0.6275)\end{array}$ & $\begin{array}{c}0.2793 \\
(0.6383)\end{array}$ \\
\hline IPO_5yr*Non-VC & & & $\begin{array}{c}-2.5122 * * * \\
(0.8205)\end{array}$ & & & \\
\hline IPO_3yr*Non-VC & & & & & & $\begin{array}{c}-2.2165 * * * \\
(0.8183)\end{array}$ \\
\hline $\begin{array}{l}\text { Time Elapsed from Patent Application to } \\
\text { Grant }\end{array}$ & -0.0323 & 0.0630 & 0.0328 & -0.0264 & 0.0487 & 0.0181 \\
\hline & $(0.0313)$ & $(0.0762)$ & $(0.0802)$ & $(0.0324)$ & $(0.0787)$ & $(0.0823)$ \\
\hline IPO Size & & $\begin{array}{l}-0.0002 \\
(0.0005)\end{array}$ & $\begin{array}{l}-0.0002 \\
(0.0005)\end{array}$ & & $\begin{array}{l}-0.0002 \\
(0.0005)\end{array}$ & $\begin{array}{l}-0.0003 \\
(0.0005)\end{array}$ \\
\hline Age of firm at the Time of Application & $\begin{array}{l}-0.0077 \\
(0.0051)\end{array}$ & $\begin{array}{c}0.0253 \\
(0.0387)\end{array}$ & $\begin{array}{c}0.0184 \\
(0.0385)\end{array}$ & $\begin{array}{l}-0.0079 \\
(0.0051)\end{array}$ & $\begin{array}{c}0.0292 \\
(0.0402)\end{array}$ & $\begin{array}{c}0.0232 \\
(0.0394)\end{array}$ \\
\hline Number of Inventors & $\begin{array}{c}0.0204 \\
(0.0211)\end{array}$ & $\begin{array}{c}0.0244 \\
(0.0294)\end{array}$ & $\begin{array}{c}0.0241 \\
(0.0289)\end{array}$ & $\begin{array}{c}0.0213 \\
(0.0209)\end{array}$ & $\begin{array}{c}0.0220 \\
(0.0301)\end{array}$ & $\begin{array}{c}0.0219 \\
(0.0297)\end{array}$ \\
\hline Number of IPC & $\begin{array}{l}\mathbf{- 0 . 0 4 9 6 *} \\
(0.0287)\end{array}$ & $\begin{array}{r}-0.1100 * \\
(0.0623)\end{array}$ & $\begin{array}{c}-0.1198 * \\
(0.0626)\end{array}$ & $\begin{array}{l}-0.0461 \\
(0.0282)\end{array}$ & $\begin{array}{l}-0.1035 * \\
(0.0615)\end{array}$ & $\begin{array}{c}-0.1116 * \\
(0.0616)\end{array}$ \\
\hline Assignee Count & $\begin{array}{c}\mathbf{- 0 . 6 0 5 1} * * * \\
(0.1473)\end{array}$ & $\begin{array}{c}-1.1915 * * * \\
(0.4291)\end{array}$ & $\begin{array}{c}-1.2030 * * * \\
(0.4405)\end{array}$ & $\begin{array}{c}\mathbf{- 0 . 6 0 0 9} * * * \\
(0.1442)\end{array}$ & $\begin{array}{c}-1.1631 * * * \\
(0.4222)\end{array}$ & $\begin{array}{c}-1.1683 * * * \\
(0.4319)\end{array}$ \\
\hline Citations Made & $\begin{array}{l}-0.0012 \\
(0.0032)\end{array}$ & $\begin{array}{l}-0.0057 \\
(0.0069)\end{array}$ & $\begin{array}{l}-0.0067 \\
(0.0072)\end{array}$ & $\begin{array}{l}-0.0012 \\
(0.0032)\end{array}$ & $\begin{array}{l}-0.0056 \\
(0.0070)\end{array}$ & $\begin{array}{l}-0.0064 \\
(0.0072)\end{array}$ \\
\hline Number of Claims & $\begin{array}{l}\mathbf{0 . 0 0 6 1 *} \\
(0.0033)\end{array}$ & $\begin{array}{c}0.0146 * * * \\
(0.0052)\end{array}$ & $\begin{array}{c}0.0143 * * * \\
(0.0052)\end{array}$ & $\begin{array}{l}\mathbf{0 . 0 0 6 2} * \\
(0.0033)\end{array}$ & $\begin{array}{c}0.0154 * * * \\
(0.0052)\end{array}$ & $\begin{array}{c}0.0152 * * * \\
(0.0052)\end{array}$ \\
\hline patent_firm_yr & $\begin{array}{c}-\mathbf{0 . 0 0 1 1} * * * \\
(0.0002)\end{array}$ & $\begin{array}{c}0.0034 \\
(0.0037)\end{array}$ & $\begin{array}{c}0.0045 \\
(0.0036)\end{array}$ & $\begin{array}{c}\mathbf{- 0 . 0 0 1 1} * * * \\
(0.0002)\end{array}$ & $\begin{array}{c}0.0033 \\
(0.0036)\end{array}$ & $\begin{array}{c}0.0043 \\
(0.0036)\end{array}$ \\
\hline $\begin{array}{l}\text { Grant year Dummies } \\
\text { Industry fixed effect }\end{array}$ & $\begin{array}{l}\text { Yes } \\
\text { Yes }\end{array}$ & $\begin{array}{l}\text { Yes } \\
\text { Yes }\end{array}$ & $\begin{array}{l}\text { Yes } \\
\text { Yes }\end{array}$ & $\begin{array}{l}\text { Yes } \\
\text { Yes }\end{array}$ & $\begin{array}{l}\text { Yes } \\
\text { Yes }\end{array}$ & $\begin{array}{l}\text { Yes } \\
\text { Yes }\end{array}$ \\
\hline Cut1 & $\begin{array}{c}\mathbf{- 2 . 0 7 1 7} * * * \\
(0.4096)\end{array}$ & $\begin{array}{c}-0.9699 \\
(1.0318)\end{array}$ & $\begin{array}{c}-0.9803 \\
(1.0488)\end{array}$ & $\begin{array}{c}\mathbf{- 2 . 0 5 6 0} * * * * \\
(0.4021)\end{array}$ & $\begin{array}{c}-0.9847 \\
(1.0365)\end{array}$ & $\begin{array}{c}-0.9982 \\
(1.0428)\end{array}$ \\
\hline Cut2 & $\begin{array}{c}\mathbf{- 1 . 2 1 2 7} * * * \\
(0.4243)\end{array}$ & $\begin{array}{l}-0.0049 \\
(1.0284)\end{array}$ & $\begin{array}{l}-0.0060 \\
(1.0474)\end{array}$ & $\begin{array}{c}\mathbf{- 1 . 1 9 5 8} * * * * \\
(0.4159)\end{array}$ & $\begin{array}{l}-0.0325 \\
(1.0321)\end{array}$ & $\begin{array}{l}-0.0393 \\
(1.0412)\end{array}$ \\
\hline Cut3 & -0.4069 & 0.7992 & 0.8040 & -0.3897 & 0.7662 & 0.7644 \\
\hline
\end{tabular}


In all models clustered Robust Std. Err. around assignee in parentheses $* \mathrm{p}<0.1 ; * * \mathrm{p}<0.05 ; * * * \mathrm{p}<0.01$ 
Table 9. Patent-level analysis: Relationship between time to IPO and the life of a patent

\begin{tabular}{|c|c|c|c|c|c|c|}
\hline & \multicolumn{3}{|c|}{ Sub-Model 1} & \multicolumn{3}{|c|}{ Sub-Model 2} \\
\hline & (1) & (2) & (3) & (4) & (5) & (6) \\
\hline Application was in $[-5,0]$ of IPO & $\begin{array}{l}\mathbf{- 1 . 7 7 1 0 *} \\
(1.0202)\end{array}$ & $\begin{array}{c}-6.3576 * * * \\
(1.7525)\end{array}$ & $\begin{array}{c}-2.1816 * * * \\
(0.9531)\end{array}$ & & & \\
\hline Application was in $[-3,0]$ of IPO & & & & $\begin{array}{c}\mathbf{- 2 . 1 3 7 9 *} \\
(1.1127)\end{array}$ & $\begin{array}{c}-5.8139 * * * \\
(1.6454)\end{array}$ & $\begin{array}{c}-2.0490 * * \\
(0.9767)\end{array}$ \\
\hline Non-VC & & $\begin{array}{c}0.7490 \\
(1.9622)\end{array}$ & $\begin{array}{c}1.4433 \\
(2.0737)\end{array}$ & & $\begin{array}{c}0.2914 \\
(1.9989)\end{array}$ & $\begin{array}{c}0.8787 \\
(2.1266)\end{array}$ \\
\hline IPO_5yr*Non-VC & & & $\begin{array}{c}-5.6012 * * \\
(2.4864)\end{array}$ & & & \\
\hline IPO_3yr* Non-VC & & & & & & $\begin{array}{l}-5.0801 * \\
(2.5726)\end{array}$ \\
\hline Time Elapsed from Patent Application to Grant & $\begin{array}{l}-0.0890 \\
(0.1134)\end{array}$ & $\begin{array}{c}0.1944 \\
(0.2359)\end{array}$ & $\begin{array}{c}0.1055 \\
(0.2499)\end{array}$ & $\begin{array}{l}-0.0710 \\
(0.1141)\end{array}$ & $\begin{array}{c}0.1369 \\
(0.2468)\end{array}$ & $\begin{array}{c}0.0454 \\
(0.2610)\end{array}$ \\
\hline IPO Size & & $\begin{array}{l}-0.0009 \\
(0.0017)\end{array}$ & $\begin{array}{l}-0.0010 \\
(0.0017)\end{array}$ & & $\begin{array}{l}-0.0010 \\
(0.0018)\end{array}$ & $\begin{array}{l}-0.0011 \\
(0.0017)\end{array}$ \\
\hline Age of firm at the Time of Application & $\begin{array}{l}-0.0298 \\
(0.0183)\end{array}$ & $\begin{array}{c}0.0870 \\
(0.1294)\end{array}$ & $\begin{array}{c}0.0662 \\
(0.1325)\end{array}$ & $\begin{array}{l}-\mathbf{- 0 . 0 3 0 7 *} \\
(0.0182)\end{array}$ & $\begin{array}{c}0.0989 \\
(0.1324)\end{array}$ & $\begin{array}{c}0.0813 \\
(0.1343)\end{array}$ \\
\hline Number of Inventors & $\begin{array}{c}0.0509 \\
(0.0707)\end{array}$ & $\begin{array}{c}0.0999 \\
(0.0893)\end{array}$ & $\begin{array}{c}0.0945 \\
(0.0877)\end{array}$ & $\begin{array}{c}0.0554 \\
(0.0700)\end{array}$ & $\begin{array}{c}0.0970 \\
(0.0895)\end{array}$ & $\begin{array}{c}0.0930 \\
(0.0878)\end{array}$ \\
\hline Number of IPC & $\begin{array}{l}-0.1501 \\
(0.0987)\end{array}$ & $\begin{array}{l}-\mathbf{0 . 3 7 9 3} * \\
(0.2008)\end{array}$ & $\begin{array}{l}-0.3905^{*} \\
(0.2033)\end{array}$ & $\begin{array}{l}-0.1372 \\
(0.0977)\end{array}$ & $\begin{array}{l}-0.3683^{*} \\
(0.2016)\end{array}$ & $\begin{array}{c}-0.3774 * \\
(0.2032)\end{array}$ \\
\hline Assignee Count & $\begin{array}{c}-\mathbf{1 . 8 4 8 1} * * * \\
(0.4900)\end{array}$ & $\begin{array}{c}\mathbf{- 3 . 4 4 5 0 * *} \\
(1.5366)\end{array}$ & $\begin{array}{c}\mathbf{- 3 . 3 9 2 3}^{* *} * \\
(1.5345)\end{array}$ & $\begin{array}{c}-\mathbf{1 . 8 6 7 5}^{* * * *} \\
(0.4783)\end{array}$ & $\begin{array}{c}-3.4140 * * \\
(1.5145)\end{array}$ & $\begin{array}{c}-3.3607 * * \\
(1.5103)\end{array}$ \\
\hline Citations Made & $\begin{array}{l}-0.0022 \\
(0.0111)\end{array}$ & $\begin{array}{l}-0.0185 \\
(0.0213)\end{array}$ & $\begin{array}{l}-0.0211 \\
(0.0216)\end{array}$ & $\begin{array}{l}-0.0022 \\
(0.0111)\end{array}$ & $\begin{array}{l}-0.0182 \\
(0.0216)\end{array}$ & $\begin{array}{l}-0.0204 \\
(0.0218)\end{array}$ \\
\hline Number of Claims & $\begin{array}{c}\mathbf{0 . 0 2 2 5}^{* *} * \\
(0.0112)\end{array}$ & $\begin{array}{c}\mathbf{0 . 0 5 0 4} * * * \\
(0.0144)\end{array}$ & $\begin{array}{c}\mathbf{0 . 0 4 9 4} * * * \\
(0.0145)\end{array}$ & $\begin{array}{c}\mathbf{0 . 0 2 3 2} * * \\
(0.0112)\end{array}$ & $\begin{array}{c}\mathbf{0 . 0 5 3 0} * * * * \\
(0.0144)\end{array}$ & $\begin{array}{c}\mathbf{0 . 0 5 2 4} * * * \\
(0.0144)\end{array}$ \\
\hline patent_firm_yr & $\begin{array}{c}-\mathbf{- 0 . 0 0 3 2} * * * \\
(0.0007)\end{array}$ & $\begin{array}{c}0.0108 \\
(0.0118)\end{array}$ & $\begin{array}{c}0.0135 \\
(0.0116)\end{array}$ & $\begin{array}{c}-\mathbf{- 0 . 0 0 3 3} * * * \\
(0.0006)\end{array}$ & $\begin{array}{c}0.0108 \\
(0.0117)\end{array}$ & $\begin{array}{c}0.0133 \\
(0.0116)\end{array}$ \\
\hline Grant year dummies & Yes & Yes & Yes & Yes & Yes & Yes \\
\hline Industry Fixed Effect & Yes & Yes & Yes & Yes & Yes & Yes \\
\hline Constant & $\begin{array}{c}\mathbf{1 5 . 3 3 6 4} * * * \\
(1.5159)\end{array}$ & $\begin{array}{c}\mathbf{1 1 . 0 3 0 3} * * * \\
(3.4971)\end{array}$ & $\begin{array}{c}11.0720 * * * \\
(3.5398)\end{array}$ & $\begin{array}{c}\mathbf{1 5 . 3 0 9 7} * * * * \\
(1.5084)\end{array}$ & $\begin{array}{c}\text { 11.1209**** } \\
(3.5186)\end{array}$ & $\begin{array}{c}11.1742 * * * \\
(3.5471)\end{array}$ \\
\hline$R^{2}$ & 0.09 & 0.19 & 0.19 & 0.09 & 0.18 & 0.18 \\
\hline$N$ & 30,891 & 6,255 & 6,255 & 30,891 & 6,255 & 6,255 \\
\hline
\end{tabular}




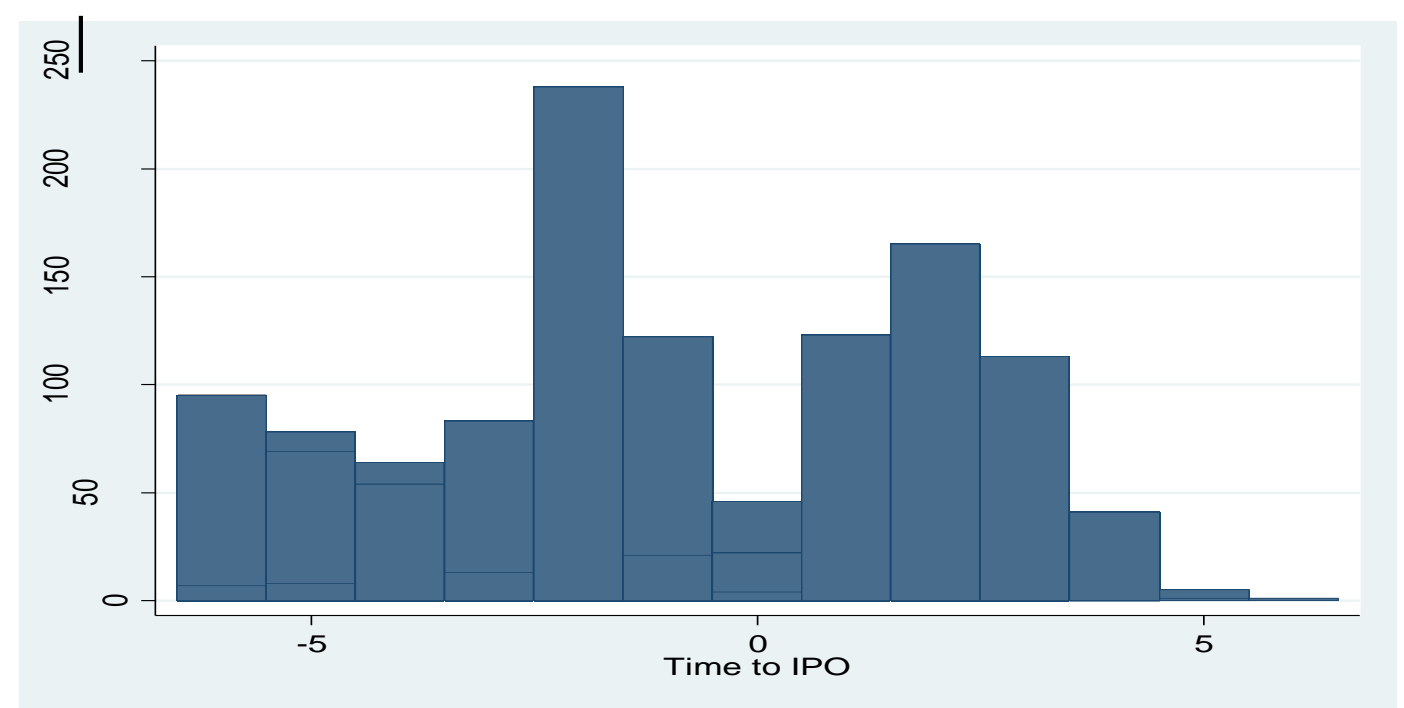

FIGURE 1

Average number of patents applied for 5 years prior to IPO to 5 years post IPO and uni-variate analysis 


\section{Variable descriptions}

\section{Appendix}

\begin{tabular}{|c|c|}
\hline Variables & Description \\
\hline \multicolumn{2}{|l|}{ Dependent Variables } \\
\hline Expired /Underutilized & $\begin{array}{l}\text { A dummy variable that receives the value of } 1 \text { if a patent becomes expired due to failure to maintenance } \\
\text { fee was used, and zero otherwise. Once a patent expires, the information contained in that patent claim } \\
\text { becomes public knowledge. For each of the patents issued in 1997, 1996, 1995, from ThomsonInnovation } \\
\text { database we extracted INPADOC Legal Status, and evaluate whether maintenance fees were paid and } \\
\text { how many times were paid. If they maintenance fees were paid three times, it means the patent completed } \\
\text { its } 20 \text { years life cycle. Similarly twice payment means patent was expired after } 12 \text { years and once payment } \\
\text { resemble expiration after } 8 \text { years. }\end{array}$ \\
\hline Expiry Year & $\begin{array}{l}\text { All patents in the database were given a value of } 4,8 \text {, or } 12 \text {, corresponding to the year the patent expired } \\
\text { due to failure of paying maintenance fees, or a value of } 20 \text { meaning the patent did not expire with the } \\
\text { assumption that if the } 12 \text { year maintenance fee was paid, then the patent will complete its life cycle and } \\
\text { lapse at } 20 \text { years. }\end{array}$ \\
\hline Number of Response & $\begin{array}{l}\text { In the ordered Logistic models, number of response represents the number of dependent variable } \\
\text { categories. In this study the dependent variable can belong to four categories: category } 1 \text { if a patent expires } \\
\text { after } 4 \text { years; category } 2 \text { : if the patent expires after } 8 \text { years; category } 3 \text { : if the patent expires after } 12 \text { years; } \\
\text { and category } 4 \text { if the patent does not expire within } 20 \text { years after application. Therefore, the number of } \\
\text { study in our ordered logistic models is four. }\end{array}$ \\
\hline \multicolumn{2}{|l|}{ Independent Variables } \\
\hline $\begin{array}{l}\text { Application was in }[-3,0] \\
\text { of IPO }\end{array}$ & $\begin{array}{l}\text { A dummy variable that shows whether the application for a certain patent has been submitted within } 3 \\
\text { years prior to the applicant's IPO year. It takes the value of } 1 \text { if so and } 0 \text { otherwise. }\end{array}$ \\
\hline $\begin{array}{l}\text { Application was in }[-5,0] \\
\text { of IPO }\end{array}$ & $\begin{array}{l}\text { A dummy variable that shows whether the application for a certain patent has been submitted within } 5 \\
\text { years prior to the applicant's IPO year. It takes the value of } 1 \text { if so and } 0 \text { otherwise. }\end{array}$ \\
\hline Non VC-backed & $\begin{array}{l}\text { The assignee did not receive VC funding after 1970. The data regarding VC investments is extracted from } \\
\text { VentureXpert (SDC Platinum). }\end{array}$ \\
\hline
\end{tabular}




\begin{tabular}{|c|c|}
\hline \multicolumn{2}{|l|}{ Control Variables } \\
\hline $\begin{array}{l}\text { Age of firm at the Time of } \\
\text { Application }\end{array}$ & The difference between a patent's application year and patent assignee's founding date \\
\hline Application Year & The year a patent was applied for \\
\hline Citations Made & $\begin{array}{l}\text { The number of citations to other patents (NBER data). Each patent lists references to previous patents. } \\
\text { Citations serve an important legal function, as they delimit the scope of the property rights awarded by the } \\
\text { patent. The applicant has a legal duty to disclose any knowledge of prior innovations. Citations Made is a } \\
\text { measure of the knowledge spillover or patent originality. }\end{array}$ \\
\hline Number of Claims & $\begin{array}{l}\text { The number of claims a patent makes. This item is extracted from the NBER dataset (Hall et al., 2001). } \\
\text { The claims specify in detail the components or building blocks of the patented invention. The number of } \\
\text { claims can be indicative of the scope or width of an invention. }\end{array}$ \\
\hline Industry Fixed Effect & $\begin{array}{l}\text { If receives a value of "yes", it means the model includes } 6 \text { dummy variables for industry fixed effect. That } \\
\text { is, the model assumes that firms in the same industry are more similar to each other than firms from other } \\
\text { industries, and it controls for this similarity. }\end{array}$ \\
\hline Founding Year & The year a firm was founded. Extracted from Thompson SDC database. \\
\hline 3 dummies for Grant Year & The year a patent was granted $(1997,1996,1995$ in this study) \\
\hline IPO Size & $\begin{array}{l}\text { The logarithm of Proceeds from IPO in } 1997 \text { million dollars. The amount of proceeds from IPO is } \\
\text { downloaded from SDC Platinum. Then to control for the time value of money, dollar values are converted } \\
\text { into equivalent } 1997 \text { dollars. IPO size is a measure of firm market value and also the amount of funding a } \\
\text { firm could raise in the market. }\end{array}$ \\
\hline Grant time & The time difference between application year and grant year. \\
\hline Inventor count & Number of inventors (extracted from Thomson Innovation) \\
\hline Assignee count & Number of assignees (Extracted from Thomson Innovation) \\
\hline $\begin{array}{l}\text { Number of international } \\
\text { patent classes }\end{array}$ & $\begin{array}{l}\text { Number of international patent classes (IPC) assigned to the patent which demonstrate how general is the } \\
\text { patent. }\end{array}$ \\
\hline
\end{tabular}




\begin{tabular}{|l|l|}
\hline Number of Patents & $\begin{array}{l}\text { This variable represents the number of patents granted to each firm during grant year (1997, 1996, 1995, } \\
\text { the basis year in this study). It is counted as the number of times a firm shows up in the database. Each } \\
\text { patent has a unique patent number and only occurs once in the database, however each firm number is } \\
\text { listed each time they are granted a patent. Number of patents can be a measure of innovativeness or } \\
\text { activity in the patenting market. }\end{array}$ \\
\hline $\begin{array}{l}\text { Clustered for Firm Fixed } \\
\text { Effect }\end{array}$ & $\begin{array}{l}\text { If receives a value of "yes", it means the model is clustered for firm fixed effect. Each firm in our sample } \\
\text { can have more than one patent granted in 1997, 1996, 1995. The clustered models then assumes that } \\
\text { patents that belong to the same firm have more common characteristics than patents from different firms, } \\
\text { and it controls for this commonality. }\end{array}$ \\
\hline $\begin{array}{l}\text { Intercept for } \\
\text { expired/expired at } \mathbf{8 / 1 2} \\
\text { years }\end{array}$ & $\begin{array}{l}\text { In the ordered logistic models, these intercepts are the estimated ordered logistics for the adjacent levels of } \\
\text { the dependent variable, not expired versus expired at 12 years, and expired at 12 years versus expired at 8 } 8 \\
\text { years, and expired at 8 years versus expired at 4 years, respectively. We use SAS to run the ordered } \\
\text { logistic models. To identify these models, SAS se the first intercept to zero, that is the intercept for expired } \\
\text { at 4 years. For more information see SAS 9.3 manual or read Greene (2003). }\end{array}$ \\
\hline
\end{tabular}

